\title{
The Development of United States Government Policy Toward Indian Health Care, 1850-1900
}

\author{
Christine Massing
}

\begin{abstract}
By 1850 the United States government already had a half century's experience providing health services to its Indian population. During the first half of the nineteenth century, however, these services were focused primarily on containing epidemic diseases, especially smallpox. By mid-cencury, the rise of intemperance and venereal diseases among Indians convinced the government that more control over Indians' health was necessary. Professionally trained physicians, bolstered by advances in medical knowledge, led this interventionist effort at improving Indian health care. Government health care providers increasingly came to believe that success depended on undermining traditional lifestyles and leadership.
\end{abstract}

The Unired States government assumed responsibility for Indian health care in 1800 under its War Department. As early as 1832, the government's treaties with Indians ${ }^{1}$ recognized the government's duty to provide physicians. ${ }^{2}$ The government's promises reflected the larger guardian role that the government had taken upon itself, as defined by the courts, to protect the Indians as parents would their children. ${ }^{3}$ In the first half of the nineteenth century, however, health care was rudimentary and often haphazard, concentrating mainly on vaccinating Indians against smallpox and containing other contagious diseases. After the Bureau of Indian Affairs was transferred to the Department of the Interior in 1849, administrators emphasized nonmilitary aspects of Indian affairs and began developing a corps of civilian field employees including physicians to deal with Indian health needs. ${ }^{4}$ Even after the termination of treaty-signing in 1871, the government had specific commitments toward at least twenty-five tribes, and a general obligation to provide health care to other Indian tribes. By the end of the century, the government clearly 
sought to monopolize the provision of health care services on Indian reservations.

The available documentary evidence shows that government interest in Indian health expanded between 1850 and 1900 from a modest program concerned primarily with containing epidemics, to an intrusive bureaucracy aimed at improving sanitary conditions in Indian communities and wresting control of health care from the hands of the medicine men. ${ }^{5}$ Several factors explain this expansion in the government's role. Beginning in 1850, the rise in instances of venereal diseases and intemperance among Indians signified to the government that the Indian needed to be educated in the ways of "civilized" Christian life. Meanwhile, advances in medical knowledge brought health into the hands of trained physicians who attempted to extinguish Indian healing practices and to bring Indians' living conditions in line with their own standards of "civilization." The reports of the Commissioner of Indian Affairs and those of Indian agents, subagents, educators, and physicians reveal the evolving policies of the United States government regarding Indian health between 1850 and $1900 .^{6}$ This study provides a general survey of government policy. Regional studies are needed to give more details and insight into local concerns.

The secondary literature in the area of Indian health generally focuses on the twentieth century, particularly on the problems facing contemporary Native peoples. ${ }^{8}$ Those works which consider Indian health in the nineteenth century fall into several categories. Many arricles discuss the effects of epidemics, particularly the smallpox epidemics of 1837-39. ${ }^{9}$ Others discuss Indian healing practices and their contributions to the medical field, especially to pharmacology. ${ }^{10}$ Research has also been done on Indian healing from a more holistic perspective, linking spirituality and healing. " Finally there are those works that discuss, to varying degrees, the work of the government, agents, and physicians in the field of Indian health care. ${ }^{12}$ Some United States government publications, especially the Meriam 
Report published in 1928, also shed light on government policy. ${ }^{13}$

Until the 1850s, the Commissioner of Indian Affairs reports mentioned Indian health mainly in terms of diseases such as smallpox, cholera, and measles that were sweeping the tribes. The devastating smallpox epidemics between 1837 and 1839 particularly caught the attention of the government. Henry Schoolcraft, Acting Superintendent of Indian Affairs in Michigan, described the fear which the epidemics instilled among the Indians in his charge:

The appearance of small-pox is sufficient, at any time, to create a panic in an Indian tribe, to whom it brings all the fears, and, when without timely relief, all the fatal consequences of the plague. Their very name for it ("Mum-mukkiz-ze-win") is a term of terror. ${ }^{14}$

Indians understood the role that settlers played in spreading disease, and sometimes took drastic measures to gain revenge. Dr. Whitman, a physician in Washington territory, was murdered by Indians under his care because they believed he spread smallpox to them. ${ }^{15}$

Like the Indians, agents realized that settlers brought diseases into Indian country and they therefore felt responsible for the health of their charges. The Commissioner's reports reflect the desperation of agents who attempted to alleviate Indian health problems without assistance from medical professionals. T. Vandenbrock, for example, took the duty upon himself of dealing with a smallpox epidemic and "visited the Indians in their own country, and vaccinated them by hundreds." 16 Agents were sometimes able to prevent the spread of smallpox, but were helpless in batcling cholera. William Bruce, in Wisconsin, attribured the cholera in his sub-agency to the addition of pork and flour to the Indian's diet. ${ }^{17}$ Other agents, such as Alfred Vaughn in Missouri, recognized that cholera was actually prompted by poor sanitary conditions, like those witnessed in the dirt lodges in which some Indians resided. ${ }^{18}$ Agents could do 


\section{Past Imperfect}

little, however, to improve the sanitary conditions in which Indians lived or to prevent the spread of disease because Indians were only beginning to settle onto reservations where agents could attempt to control their living standards. ${ }^{19}$ Furthermore, agents lacked the medical training and the financial resources with which to deliver adequate health care or to educate Indians in disease prevention.

Indian agents consequently lobbied the government for physicians and medicine. ${ }^{20}$ Even in cases where the government permitted agents to hire physicians, willing physicians were often difficult to find. Michael Simmons, an agent in Washington, wrote that

a physician is also allowed by treaty stipulations, but for the last nine months I have not been able to employ one. The amount of compensation is so small that no professional man will accept the position. ${ }^{21}$

Many other reports confirmed that three hundred dollars per year would not attract physicians. ${ }^{22}$ Indian agents lobbied for the provision of physicians on purely humanitarian grounds. William Armstrong, acting superintendent in the Western region, stated that "nothing is allowed them [Indians] by government for medicines or medical attendance. This I cannot but regard as wrong." ${ }^{23}$ Another agent, John Miller in Missouri, wrote an impassioned piece about Indians which he found suffering from typhoid until he gave them some quinine he had brought for his personal use: "I have troubled you with this digression merely to show you that a very small outlay for medicine would save much suffering, and many lives." ${ }^{24}$ Indian agents realized that their efforts in the area of health care were insufficient and struggled to overcome their deficiencies by urging the government to provide reservations with physicians.

Between 1850 and the 1880 s, several factors caused the government to change policies toward Indian health. The rapid spread of health problems caused by what was deemed as immoral behaviour provided the first inducement 
for the government to exert greater control over Indian health care. As settlers pushed farther into Indian territory, demands for land exacerbated tensions between settlers and Indians. Unethical traders brought liquor to Indians and, beginning in the early 1850 s, many agents expressed concern about intemperance for both moral and health reasons. A number of reports document how "the intemperate use of ardent spirits" led to Indians' deaths. ${ }^{25}$ By lobbying to keep unethical traders away from the Indians, agents aspired to eliminatealcohol-related health problems. ${ }^{26}$ Agents, however, also connected the consumption of liquor with immorality and the spread of venereal diseases.

With increased contact between Indians and settlers carne a rise in the incidence of venereal diseases, particularly syphilis. P. P. Wilcox, agent in California, explained the spread of venereal diseases as the result of "licentious habits, and it is a fact worthy of notice that the immoral practices that lead to this affliction are more common among those bands that are on the most friendly and intimate terms with the whites than among the more warlike." ${ }^{27}$ Agents and physicians were sensitive to the debilitating effects of venereal diseases. Many agents discussed the transmission of disease from generation to generation, noting that children suffered because "their parents have eaten sour grapes." 28 They were also disturbed that Indians' reproductive capabilities were being destroyed completely. ${ }^{29}$ Indians clearly needed to be protected from these diseases.

The concern about venereal diseases and intemperance provided one justification for the government to contain Indians on reservations. By isolating Indians, the agents could better control the contacts between settlers and Indians and deal with the health problems that had already emerged. Henry Ford, a sub-agent in California, articulared this need for reservations: "The diseases mostly prevalent are those brought on by the imprudence of the Indians themselves, and by promiscuous connexion with the whites, which shows, if more proof were needed, the propriety of removing them to this and other reservations." ${ }^{30}$ Whites who were 


\section{Past Imperfect}

most frequently in contact with Indians at the rime were described by one contemporary as the "scum and dregs of society." ${ }^{11}$ They were not only poor behavioral models for the impressionable Indians, but encouraged Indians to indulge in these vices. ${ }^{32}$ Most reports, however, placed the blame for the spread of venereal diseases not on settlers, but on Indians who were seen as immoral. ${ }^{33}$ Agents hoped that the morality of Indians could be uplifted and venereal diseases eliminated with the strategic use of religious education, much more easily provided on reservations than in nomadic communities.

Observers in the nineteenth century attributed the gradual decline of the Indian population to disease and to vices such as alcohol consumption. Assimilation and proper education were necessary, they argued, to civilize and to save the Indians. In 1865, at the end of the Civil War, the government began offering financial aid to missionary organizations in order to help them establish schools that would teach mechanical and agricultural skills. This government-missionary alliance was the foundation of efforts to assimilate Indians, not through military force, but through Christian teaching. ${ }^{34}$ Christian reformers were guided by two authorities, the Bible and the Declaration of Independence, both of which, in principle, recognized all persons as equal, as brothers and sisters. ${ }^{35}$ The reformers rejected the idea that Indians were biologically inferior and slow to change, clinging to a form of cultural determinism which viewed Indians as less advanced in the progressive transition from savage to civilized. ${ }^{36}$

The reformers believed that individualization was the key to civilizing Indians, and, therefore, they sought to divide tribal lands among individuals and break up tribal authority. Reformers sought to imbue "civilized" Indians with Christian values that would make the family, not the tribe, the basic social unit; encourage individuals to labour industriously on plots of land; and embrace Christian virtues by eradicating customs such as polygamy. ${ }^{37}$ The government passed the Dawes Act in 1887 to assist in 
attaining these goals. The Act allotted land to individual Indians to be held in trust by the government for twenty-five years so that Indians could prepare themselves for the duties of citizenship. ${ }^{38}$ During this time, the Bureau of Indian Affairs became the dominant institution on the reservations. ${ }^{39}$

In 1873, the administration of Indian health care was centralized within the Bureau of Indian Affairs with the creation of a Division of Education and Medicine, entrusted with the task of organizing central reporting and distriburing medical supplies. ${ }^{40}$ The bureaucratization of Indian health and the subsequent placement of more physicians on the reservations led to a shift in the aims of the administrators. The focus on curbing epidemics and promoting morality changed to include more detailed analyses of health problems and the sponsorship of preventive measures.

Developments in the medical profession influenced the shift of Indian health policy. Before the latter half of the nineteenth century, the miasmatic theory of disease, dating back to the time of Hippocrates, dominated medical thought. ${ }^{41}$ According to the miasmatic theory, certain atmospheric conditions caused illness. ${ }^{42}$ For example, malaria, contracted in marshy areas, was attribured to noxious gases emanating from swamps. ${ }^{43}$ Miasmatic theory held that poor sanitary conditions caused an atmospheric state conducive to infectious diseases. ${ }^{44}$ Consequently, many health reformers, referred to as sanitarians, worked vigorously throughout the nineteenth century to improve living conditions.

The contagion or germ theory altered this prevailing view of the causes of contagious diseases. In the late 1600 s, Anton van Leeuwenhoek first observed, using a microscope, bacteria and other organisms that some scientists later claimed were the agents of contagious diseases. ${ }^{45}$ The contagion theory, however, could not be proven until the latter half of the nineteenth century. Improvements in the sanitary conditions in which people lived was now regarded as critical, not because filth created "bad air," but because it fostered the growth of disease-causing bacteria. Thus, while 


\section{Past Imperfect}

not every reservation physician accepted the contagion theory fully, the idea certainly affirmed the need for better sanitary conditions.

This modern explanation of disease also had the effect of removing public health matters from the hands of the untrained into those of the scientifically trained professionals. ${ }^{46}$ The descriptions and accounts of the illnesses and diseases affecting Indians clearly reflects this shift. Whereas Indian agents had usually referred to the ailments affecting Indians with vague descriptions like "fevers and chills," 47 physicians employed scientific terminology. Beginning in 1880 , the yearly reports included detailed charts showing the number of cases and the nature of diseases treated by physicians. ${ }^{48}$ Surgery, which went from being an infrequent event to a common form of treatment, revealed the extent to which health had become professionalized. ${ }^{49}$

A policy paper, sent in 1889 by the Bureau of Indian Affairs to all applicants for positions as agency physicians, reveals how the role of the health care provider had expanded: ${ }^{50}$

The agency physician is required not only to attend those who call upon him at his office, but also to visit the Indians at their homes, and in addition to prescribing and administering needed medicine, to do his utmost to educate and instruct them in proper methods of living, and of caring for health. He should exercise special care in regard to the sanitary condition of the agency and schools, and promptly report to the agent any condition, either of buildings or grounds, liable to cause sickness, in order that proper steps may be taken to remedy the evil.s1

Not only was the physician expected to define clearly the health problems facing the Indians, but he also had to address the causes and to deal with them in ways beyond simply administering medicine. Physicians and agents were responsible for improving nutrition, clothing, living 
conditions, and for Indian health generally. Physicians believed that Indian living conditions had to be changed not only to prevent diseases, but to civilize and assimilate Indians by having them live as whites did. ${ }^{52}$

Physicians hoped that the starvation that many Indians faced in the past could be alleviated. Many factors could affect the food supplies of Indians, including crop failure and stolen or misdirected supplies. During the Civil War, these problems were intensified, especially in the Southern superintendency where agent George Cutler worried about theft. "The cartle supply," he wrote, "which was deemed almost inexhaustible, is growing short every day; large droves of cartle are being driven north by cattle-thieves continually." " 33 Agents required military assistance to curb these thefts, but the military was preoccupied by the war and therefore surplus men were impossible to find. At the conclusion of the war, however, food supplies were not necessarily any greater. A Nebraska agent, George Wilkinson, expressed his concerns about Indians' nutritional needs: "When the Indian learns to eat healthy food in proper quantities he will be more healthy, for most of his diseases are from insufficient nourishment. ${ }^{\text {"1 }}$

Physicians were concerned that Indians who had sufficient food learn how to prepare meals properly. Dr. C. H. Kermott, in Dakota territory, noted that the "Indians prepare their food in such a manner that it becomes a vehicle whereby many a parasitical and disease germ is carried into the system." 95 Poor nutrition was not only seen to cause illness, but also to hinder the recovery of the sick. Many physicians advocated the employment of knowledgable cooks to prepare "suitable nourishment for the sick." 56 If Indians were provided with food with which they were unfamiliar, however, it seems to explain why they may have been unable to cook it properly. Agents and physicians worried about nutrition for health reasons, but also insisted that Indians cook and eat as they did themselves.

Inadequate clothing, physicians also urged, led to health problems among Indians. Joseph Finney, a physician 
in North Dakota, asked above all for "good, substantial, waterproof foot gear" for the Indians, and John Littlefield in Colorado requested rubber overshoes for the prevention of illness. ${ }^{57}$ Inevitably, in advocating better clothing, physicians insisred that Indians' style of dress be similar to that of the whites. Charles Willoughby, an agent in Washington, argued that a "mark of progress is the number [of Indians] who wear citizens' dress." "Civilized dress" was deemed to be superior for reasons of "comfort and health." and agents undermined Indians' traditional styles of dress by supplying them with clothing that fit white conceptions of how "civilized" people ought to dress.

Agents and physicians also considered Indian dwellings to be inadequate and uncivilized. ${ }^{60}$ According to Gordon Winslow, an acting agent in California, once Indians discarded their "primitive" habitations and adopted dwellings "similar to a white man's," their health would improve and "civilizing results" would be seen. ${ }^{61}$ The houses which were constructed to replace traditional dwellings, however, were often of poor quality with dirt floors that spread diseases. C. A. May, a physician in South Dakota, described the problem with Indian housing:

I found the greater part of them in a rather poor sanitary condition; dirty, litcle to eat, living in little logs houses, one room, a whole family eating and sleeping in the same room; a stove in the middle of the room and the heat very grear; sod roof, which leaks very bad [sic] when the weather is wet; ground floor, damp and foul. I find it of little use to try to do much for the sick in these houses, for if any acute trouble attacks them they are sure to die. ${ }^{62}$

Stoves inside these houses were also the source of many complaints because smoke often caused diseases of the eye, such as conjuncrivitis. ${ }^{63}$ The nutrition, clothing, and homes of Indians were gradually transformed according to what 
agents and physicians deemed civilized and appropriate for their physical well-being.

Physicians also undermined other aspects of traditional Indian life. Sweat houses, for example, were thought to promote disease. The purpose of a sweat house, from the Indian point of view, was physical and spiritual. A sweat house cleansed and served as a "panacea for all diseases." 64 Some physicians acknowledged the benefits of a sweat house, but believed, as did Dr. Eugene Clark from Oregon, that "the extremes to which most of them carry this process of sweating for every ailment and in any stage is a decided detriment." 65 The practice of following a sweat bath with a plunge into cold water invoked sharp criticism from physicians. Dr. R. J. Pilkington from Oregon described the process:

a small dirt and brush oven into which hot stones and water are carried, and a steam generated that I have found would bring the temperature to $180 \mathrm{~F}$. Into this oven from 3 to 10 Indians crawl, and, packed in like sardines, they lie and perspire for a long time. I have seen them come out and break through 6 inches of ice to get into the cold water. It is the Russian bath in such a crude form that its use is very injurious to the constitution of the Indian. ${ }^{66}$

There was a basis for these concerns because some Indians did use the sweat bath for treating diseases such as smallpox. with facal results. ${ }^{67}$

Health was also a particular problem in the schools because illness interfered with learning and with attempts to acculturate Indian children. In countless reports, teachers bemoaned interruptions of lessons because of illnesses. ${ }^{68}$ When illness broke out, some parents simply kept their children at home. P. Dougherty, who taught at the Grand Traverse Presbyterian Mission and School in Michigan, declared that 
two promising boys died last year from diseases of the brain. There seems to have been an impression on the part of parents and others, that their attendance on school had some influence in inducing the disease. This feeling, I apprehend, has influenced parents to be less urgent on their children to attend school regularly. ${ }^{69}$

Since schools were intended to civilize and acculturate Indian children, it was a considerable setback if students returned home to live traditionally or were unable to attend school. Dr. George Martin, from Montana, argued that "since all the advancement of these people in civilization must be through their children, the health of children becomes a vital part of the Indian question." 70 Once the civilization of the Indians became a priority, moreover, the health of children took on a new sense of urgency. ${ }^{\text {" Physicians }}$ working at the schools not only rendered treatment according to necessity, but also promoted preventive health by instructing students in basic physiology and hygiene. Physicians found, however, that if they were to alter or eradicate certain Indian ways of life, they first needed to diminish the authority of the medicine men.

Medicine men possessed a great deal of power within Indian tribes. Medicine men were not only healers, but respected religious and tribal leaders. One agent wrote about the hold that medicine men had over the rest of the tribe: "An Indian doctor has but to spit on the ground and make certain meaningless signs to awe the stourest of them."72 As influential tribal figures, the medicine men were denounced by agents and physicians because they represented the traditional beliefs that were enemies of assimilationist policies.

Indian agents and physicians expressed dismay, if not outright hostility, toward medicine men for several reasons. The most obvious reason was that medicine men eroded the power that agents held over their Indian charges. Agents desired absolute control over Indians to realize their chief 
goals in Indian policy: civilization and assimilation. ${ }^{73}$ The influence of medicine men was thought to hinder the extinguishment of Indian culture and the "absorption of new ideas and the adoption of new customs. ${ }^{.74}$ Commissioner Hiram Price endorsed the idea that medicine men were obstacles to civilization efforts and exhorted agents to work actively toward eliminating their authority. ${ }^{75}$ Agents, like Charles Willoughby in Washington territory, echoed Price's sentiments: "To destroy their belief in their medicine men, who are ever the enemy of the whites, inasmuch as the presence of the latter is a signal for their overthrow, is to make a huge stride toward civilizing the Indians." ${ }^{76}$

By the 1880s, physicians could be found on the reservations in sufficient numbers to condemn medicine men on more specific charges related to health care. Physicians frequently asserted that the reliance of Indians on traditional healing practices betrayed their lack of civilization. The physicians' preoccupation with medicine men was central to their struggle to replace traditional healing practices with modern medical practices. Progress was clearly attainable only by eliminating the untrained and unscientific medicine man. ${ }^{77}$

Although physicians, more than agents, fuelled the attack on medicine men, they did not understand Indian medical practices, partly because of a language barrier ${ }^{88}$ and partly because they evaluated Indian medicine by their own standards. ${ }^{79}$ Physicians usually described Indians' health practices as "Indian jugglery, known as 'medicine,' and consisting mostly of drumming, shouting, and screaming, to appease the wrath of the Great Spirit." ${ }^{\text {"80 }}$ The shouting was seen as particularly offensive, and described with such phrases as "unearthly noise"81 and "hideous incantations." 82 Physicians often complained that medicine men subjected patients to cruel and harsh treatment such as "burning the sufferer in a most inhuman manner." ${ }^{183}$ Agents and physicians viewed as superstitious Indians' beliefs that the spirit is captured within the structure in which a person has died. Dr. William Warren from Oregon wrote that "in accordance 
with their savage superstitions, when the case to them seems hopeless, turn the invalid out of doors to die alone." ${ }^{84}$ This belief, however, explained why many Indians resisted staying in the hospitals, which they believed to be filled with the spirits of those who had died there. As one physician, Dr. Z. T. Daniel, wrote, Indians had "an aversion to being sick in a house where a corpse has lain." ${ }^{85}$ Thus, physicians and agents atrempted to discredit medicine men by dismissing the validity of their healing methods.

Agents, and the occasional physician, also engaged, however, in personal attacks on individual medicine men. Agents especially accused medicine men of greed because they demanded payment for healing services. One report, for example, discussed how the medicine man in effect manipulated his patients "to part with a blanket or similar articles for the sake of having jugglery performed over them." ${ }^{86}$ James McLaughlin, an agent in Dakota territory, censured a medicine man for "feasting" on food left for the patient. ${ }^{87}$ According to agent John Roork of Oregon, Indians themselves recognized the avarice of their medicine man: "they think that he makes them sick for the purpose of extorting a fee from them for the cure." ${ }^{88}$ Medicine men, like the physicians themselves, however, were not unreasonable in demanding some form of payment for their services. Agents often censured medicine men based on other personal characteristics, such as ignorance or dishonesty. Oregon agent Alonzo Gesner was typical in expressing the contempt he felt for the medicine man in his agency:

He is extremely conservative; he is tyrannical, indolent, worthless, and dishonest. He only studies how well he may deceive his people so as to gain a living without carning it; and he succeeds only too well in his pretended necromancy. And either through fear, ignorance, or superstition there are none but what admit his power to cure or kill at will.9" 
It is conceivable that some medicine men did exhibit such characteristics, but physicians also needed to undermine medicine men's credibility for professional and personal reasons.

Physicians and agents considered education, however, as the principal means by which Indians would come to reject the influence of medicine men. In regions where schools had been established and had been relatively successful in civilizing and assimilating Indian children, the children did gradually reject some traditional ideas. Henry King, a special agent in Minnesota, wrote: "Their old men complain that no young men are in training to perpetuate this form of superstitious hearhenism-for such it really is." ${ }^{90}$ Indian children, then, could be taught to reject the medicine men in the schools.

Those Indians who were of mixed blood also seemed more inclined toward discarding traditional healing practices. Arkansas agent George Butler wrote:
Many of the full-blood Cherokees yet have a great aversion to the medicine of the regular faculty, and prefer the roots and herbs of their own native doctors. The more enlightened portion are fast losing that prejudice, and always call in a regular physician when one can be had. ${ }^{91}$

It is apparent from the reports that the "enlightened" Indians only included those who were of mixed blood, or were educated by whites. Agents and physicians thought fullblooded Indians clung to traditional ideas because they did not have as much exposure to the "superior" ways of the whites. L.J. Miles, an agent in Indian territory, noted, for example, that the medicine men controlled the full bloods in his agency, and the latter were thus deprived of the "good results" the agency physician could produce. ${ }^{92}$ Agents, then, clearly perceived a connection between being of mixed blood and being "civilized." 
Agents and physicians hoped that as the older people who clung to traditional health practices died, the medicine man would lose his influence over younger Indians. ${ }^{93}$ Because of their "backward" ideas, older Indians were believed to be obstacles to scientific medicine and new ideas. Claude Covey, an agent in Washington, echoed common beliefs about aged Indians. He asserted that "the older nonprogressive element live in filth, with no regard for health or appearance." 94 The older Indians, however, were highly respected for the most part and could successfully advocate the use of medicine men. ${ }^{55}$

Physicians strongly lobbied for the construction of hospitals, mainly out of humanitarian concern for their patients, but also to diminish the influence of medicine men. ${ }^{96}$ Physicians considered hospitals essential to keep Indians out of unsanitary conditions in their homes and to keep them adequately sheltered from the elements. ${ }^{27}$ Cicero Newell, an agent in Dakota territory, summed up the argument about the need for hospitals:

If respectable hospital accommodations were provided, where the physician could visit daily, and have the entire supervision in the treatment of serious cases, I should consider it an act of humanity. Under the existing circumstances these cases linger along in the poor shelter afforded by their tepees, and under the treatment of their native medicine man, until death terminates their miserable existence. ${ }^{98}$

Furthermore, the spread of diseases could be controlled in hospitals. A physician from South Dakota, Dr. C.A. Wray, affirmed that the "afflicted ones sleep in the same rooms and eat at the same tables with the ones that are in good health, which can not help but be a detriment from a sanitary standpoint." ${ }^{\text {"99 }}$ The hospitals, however, served an additional function in deterring Indians from seeking out the medicine man or preventing patients from ignoring the orders of the physician, thus increasing the physician's control of the over 
Indian health. Physicians often found that their Indian charges were reluctant to follow their prescriptions precisely, and lacking "knowledge of the ways of the white people in administering medicine, [did] not take the remedies given them by the physician with any degree of punctuality." 100 In hospitals, however, physicians could closely monitor their patients and ensure that the treatments were heeded. Hospitals served to lessen the influence of medicine men, to contain diseases, and to care for parients in a "civilized" fashion.

With the growth of professional medicine came the movement toward licensing medical practitioners. Professional medicine seemed to legitimize the control that physicians sought to wield over Indians. By the later part of the nineteenth century, the measure of physicians' competence rested on whether they possessed a medical degree. Most of the states passed legislation on medical licensing by the end of the century, although these laws were difficult to enforce. ${ }^{101}$ After 1878, the Indian Service physicians were required to have medical degrees. ${ }^{102}$ This new requirement had ramifications for all those who practiced medicine on the reservations. Indian agents sometimes attempted to use the legislation to eliminate the influence of medicine men. Andrew Caldwell, an agent in Idaho, noted that "medicine men continue to be a hindrance to proper medical attention," and that he "had some of them arrested for practicing their own rites." 103 In some cases, arresting medicine men was a difficult undertaking because Indian police refused to become involved. As another Idaho agent, S. G. Fisher, complained:

It is next to impossible for an agent to punish them for their misdeeds, from the fact that no Indian policeman can be induced to arrest one of them; neither will any member of the tribe appear as a witness against one of them, believing as they do that a "medicine man" has supernatural power and to incur his displeasure would place the offender entirely at his mercy. ${ }^{104}$ 
This statement suggests that medicine men still held a considerable amount of influence over the tribe.

In largeagencies, physicians found it extremely difficult to hold any measure of control over Indian health. Many physicians travelled miles between patients on inadequate roads, by horseback, or in poorly maintained buggies. One Oklahoma physician, for example, practiced among 4,121 Indians in an area of 5,801 square miles. ${ }^{105}$ In 1886 , agent Charles McChesney from Dakota requested in his report that a team of horses and buggy be supplied to Dr. Barbour because his work required a great deal of travel over a large area. ${ }^{106}$ Although agents lobbied for improvements in transportation, the conditions were not ameliorated, to the detriment of Indians' health. An agent in California declared:

Notwithstanding the efficiency and earnestness of my physician there are hundreds of sufferers scattered all over this agency whose feebleness and poverry make it impossible for them ever to see the physician. They lie in their dismal huts and pine for the healer, but he never comes. ${ }^{107}$

Even when physicians could reach patients in time to diagnose the illnesses and give medication, they usually could not follow through with the treatment. Medicine men would administer to the sick in the absence of physicians, to the frustration of Indian agents. According to California agent John Burchard, the treatments given by medicine men often did not harmonize with those of the physician, with unfavourable and sometimes fatal results. ${ }^{108}$

Although physicians and agents attempted to control Indian health care through education, hospitals, and improvements in service, their success can only be measured by the responses of Indians themselves. Those Indians who still visited the medicine men, according to the reports, did so out of a combination of fear of the medicine man and lack of confidence in the physician to treat certain ailments. One agent reported that 
the medicine men exercise a great influence over the rest of the tribe, and the common people believe that they possess the power, when they displease them, of punishing them by inflicting them with great calamities. ${ }^{109}$

In cases of extreme or dangerous illness, many Indians would also resort to the medicine men, even if they had been seeing the physician regularly for more minor concerns. ${ }^{110}$ John Smith, an agent in Utah, expressed this common theme: "The Indians seem to have confidence in the physician for small troubles, but for any of magnitude they prefer their own doctors, that as surely kill them." 111

In other cases, depending on the degree of confidence that Indians had in physicians, Indians began to trust their skills. If physicians were particularly good, they were usually able to gain more support from the Indians. Such was the case with one physician from Dakota territory, as reported by Indian agent W. T. Hughes:

Some very remarkable cures have been performed by our agency physician (who is a very skilful young gentleman) during the past year. His success in treating the sick Indians has given them great confidence in him, and caused a large proportion of them to abandon the treatment of the medicine men. ${ }^{112}$

Howard White, an agent in New Mexico, observed, however, that if the physician did not produce a "speedy cure" Indians would then go to see a medicine man. ${ }^{113}$ Indians, then, would more conscientiously see physicians and follow their directions if they respected the white doctors. ${ }^{114}$

While many Indians did visit physicians, they often displayed an intense aversion to hospitals. Hospitals prevented the practice of traditional Indian customs by placing the sick under the watch of the physician and away from other Indians. As Dr. Z. T. Daniel, from South Dakota, wrote: 
The patient is put on a sick diet, which, to him, is synonymous with starvation. They are under restraint in everything in a hospital. There can be no drumming, incantations, songs, etc.; they cannot receive presents from sympathizing friends as easily and readily as in the camp ... it is another world to them.... They never think of the cures, relief, and good things done in a hospital; their attention is continuously fixed on the deaths and failures."

Indians did resist being put in hospitals. Dr. Daniel reported on a boy who had broken his leg:

The parents, uncles, and aunts, and 1 believe the grandfather, collected in a crowd in the apartment, and made such a noise and protest at the proposition to keep the boy there that we decided it was best to let them take him to his Indian home. ${ }^{116}$

Hospicals made consultations with medicine men impossible. Moreover, hospitals represented a complete alteration in the traditions and belief systems that Indians, to varying degrees, continued to hold.

Physicians expressed a great deal of frustration over the fact that some Indians visited them but failed to follow the instructions given to them. James McLaughlin, an agent in Dakota, noted that Indians "always take the medicines home with them, but on visiting them the following day the medicine will usually be found untouched, and some medicine-man engaged in incancations, drumming and singing." 117 Reports outlining the failure of Indians' to follow physicians' directions are common and suggest that Indians tried to please agents and physicians by submitting themselves to a scientific form of medicine while secretly practicing their own beliefs. James McLaughlin hinted at this element of secrecy when he described how Indians practicing traditional healing rites endeavoured "to avoid being seen by the whites or Christian Indians." 118 One 
questions the degree to which most Indians did suppress traditional ideas when they could be observed by the agent. One of the most telling phrases in this respect was from Peter Ronan, an agent in Montana, who said that "such thing as Indian 'Medicine Men' have no existence, to my knowledge, on this reservation." 119 Comments such as these suggest that many traditional aspects of Indians' lives were actually clandestine, and agents and physicians often had no idea about the extent of the influence of medicine men.

A few Indians responded favourably to the white medical practices in that they entered medical schools themselves. In 1890, the Commissioner of Indian Affairs viewed the graduation of three Indian doctors-Dr. Charles Eastman, Dr. Carlos Montezuma, and Dr. Susan LaFlesche-as evidence that "Indians are coming into closer relations with civilized society." 120 Susan LaFlesche was an acculturated mixed-blood woman who had attended a mission school. ${ }^{121}$ Rather than become a healer or shaman on her Omaha reservation, she chose to attend a medical college and practice as her reservations' physician. While many Indians rejected the practices of physicians, others accepted the new medical practices to varying degrees. An Oklahoma physician, George Westfall, commented on how Indians were "beginning to realize that their way is not the best way, and that a more rational and enlightened system based on experience and faith in the potency of the white man's medicine is beginning to assert itself." ${ }^{22}$ It is likely that some Indians believed that it was easier to work within the white medical system than to defy openly the wishes of Indian agents by becoming traditional healers.

The Meriam Report illustrates that, even by 1928 , physicians and agents were unsuccessful in extinguishing the influence of the medicine man:

The medicine man is still a potent factor among the tribes. In some tribes the general impression gained is that his influence is gradually diminishing, but many still practice the same old incantations and religious rites. ${ }^{123}$ 
The physicians, then, had been forced to accept the role of medicine men in the health care system. Language barriers and distrust in the abilities of the physicians inspired many Indians to continue to use medicine men. The campaign to eliminate their influence seems to have been, by this time, effectively abandoned. Agents and physicians likely realized that, until they had the facilities, equipment, and personnel to render comperent medical aid, they were in no position to deprive Indians of their traditional ways of coping with illness. ${ }^{124}$ The fact that present-day health care for Indians often integrates traditional healing practices with mainstream medical practices illustrates the high degree of cultural survival in Indian health care.

The United States government policy toward Indian health care, as reflected in the Commissioner of Indian Affairs reports, moved through stages of increasing professionalization and intervention. Early writings on health were preoccupied with diseases of an epidemic nature or other ailments which were vaguely defined by agents. Beginning in the 1850s, the focus of Indian health shifted as intemperance and venereal diseases convinced the government that reservations were needed to contain the diseases and limit contacts with setclers. Christian reformers were urged to aid in the civilization and assimilation of Indians. More physicians also joined the ranks of the Bureau of Indian Affairs and, bolstered by advances in the medical field, sought to take control of Indian health out of the hands of the medicine men. The reports were riddled with details about the nature and causes of diseases affecting Indians. The prevention of disease through proper sanitary measures became of the utmost importance and served to extend the control of the agents and physicians over many aspects of Indians' lives. It is important to recognize, however, that these agents and plysicians were not merely grasping for power in their efforts to consolidate their control of Indian health; rather, they had a genuine concern for their wellbeing. ${ }^{125}$ 
The language employed by physicians and agents is often condescending and clearly reflects the dominant attitude at the time of the superiority of white, or scientific, over Indian, or "primitive," medical practices. Yet, it seems that physicians and Indian agents were not entirely successful in their policies of controlling Indian health through sanitation and undermining the credibility of Indian methods of healing. While some Indians did accept the policies that the U.S. government imposed, many more appeared to have integrated the ideas of white medical practitioners within their own belief systems, or resisted al together the imposition of whice values on their ways of life. 


\section{NOTES}

'The author has chosen to use the term Indian rather than notive, and white instead of non-native, because these are the terms used in the primary sources.

2 United States Department of Health, Education, and Welfare, Health Services For American Indians (Washington D.C., 1957), 86

${ }^{3}$ For a detailed description of the Marshall legal decisions which defined this relationship between Indians and the government, see Charles Wilkinson, American Indians. Time, and the Law (New Haven, Conn. and London, 1987); Vine Deloria and Clifford Lytle, American Indians, American Justice (Austin, Tex., 1983); or William Canby, American Indian Law in a Nutshell (St. Paul, Minn., 1981).

1 United States Department of Health, Education, and Welfare, The Indian Health Program of the U.S. Public Health Service (Washington D.C., 1966), 18

'In this paper, Indian healers will be referred to as medicine men because that is the term used in the primary sources. Only two references are made to women as follows: "Doctoring among the Indians is not confined to men alone, but the women are possessed with the power to heal as well as the men," $(1885,400)$ and "There are many native medical practitioners, both male and female ..."(1876, 102) These references are found in: United States Office of Indian Affairs, Annual Reports of the Commissioner of Indian Affairs(Washington D.C.. 1849-69. 1871-86, 1890-1899) and United States Department of the Interior, Annual Reports of the Department of the Interior Indian Affairs, Part I (Washington D.C., 1901-1909). The reports covering the years between 1824-1848 are found in: United States Office of Indian Affairs, Annual Reports of the Commissioner of Indian Affairs (New York. 1976). These reports will be referred to as the ClA Reports, followed by the year and page number.

- Most of these reports are signed only with the first initials and surnames of the agents, physicians, and other administrators. The first names have, for this paper, been derived from Edward E. Hill. The Office of Indian Affairs. 1824-1880: Historical Sketches (New York. 1974). This work contains information on the agencies and superintendencies, as well as the names of the administrators. For biographical information on the Commissioners and their work, see Robert M. Kvasnicka and Herman J. Viola, eds., The Commissioners of Indinn Affairs, 1824-1977 (Lincoln, Neb., 1979). This work does not, however, discuss the Commissioners' policies toward Indian health.

This author recognizes that although health care varied widely based on tribal and geographical differences, specific themes can be identified which seem to represent the policies of Indian agents. It is important to note that Indian agents and physicians were expected to cover 
expansive areas in their work. Differences exist, then, depending on how close the contact was between Indians and agents and physicians. Some Indians were by necessity excluded from policies in early years because agents did not have any control over their movements.

${ }^{3}$ See, for example, the series of articles found in the American Indian Culture and Research Journal 1 3,3 \& 4 (1989), Robert Kane and Rosalie Kane, Indian Health Care (With Reservations!) (New York, 1972), Jon F. Rice, "Health Conditions of Native Americans in the Twentieth Century," Indian Historian 10,4 (1977), 14-18. For a strictly medical analysis, see David Rabin, Bascom Anthony, Saul Harrison, Health Problems of U.S. and North American Indian Populations (New York, 1972); or Pan American Health Organization, Biomedical Challenges Presented by the American Indian (Washington D.C., 1968).

'See, for example, Marguerite Jensen, "The Mandan Tragedy," Indian Historian 15,3 (1972), 18-22. John C. Ewers, "The Influence of Epidemics on the Indian Populations and Culcures of Texas," Plains Anthropologist 18,60 (1973), 104-1 15. Clyde Dollar, "The High Plains Smallpox Epidemic of 1837-38," The Western Historical Quarterly 8,1 (1977), 15-38. K.C. Tessendorf, "Red Death on the Missouri," American West 14,1 (1977), 48-53. William Allen Pusey, "The Smallpox Epidemic Among the Mandan Indians in 1837," The Journal of the American Medical Association 95,26 (1949), 1992-4.

${ }_{10}$ For examples of these works, see Virgil Vogel, American Indian Medicine (Norman, Okla., 1970), Eric Stone, Medicine Among the American Indians (New York, 1932).

"See, for example, Ruth Underhill, Red Man's Religion: Beliefs and Practices of the Indians North of Mexico (Chicago, 1965); John Collins, Native American Religions: A Geographical Survey (Lewiston, Wales, 1991); C.A. Weslager, Magic Medicines of the Indians (Somerset, N.J., 1973); or the numerous works of Ake Hultkrantz.

${ }^{12}$ See J.G. Townsend, "Indian Health-Past, Present, and Future," in The Changing Indian, Oliver LaFarge, ed. (Norman, Okla., 1942), Francis Paul Prucha, The Great Father: The United States Government and the American Indians (Lincoln, Neb. and London, 1984), Virginia R. Allen, "Agency Physicians to the Southern Plains Indians, 18681900," Bulletin of the History of Medicine 49,3 (1975), 318-330.

${ }^{13}$ See especially Health Services for American Indians as cited previously. Also see United States Department of Health, Education, and Welfare, The Indian Health Program of the U.S. PublicHealth Service (Washington D.C., 1972) and Lewis Meriam, The Problem of Indian Administration (Baltimore, 1928).

14 CIA Report, 1840, 350

15 CIA Report 1854, 284 and 223 describe the fate of Dr. Whitman. See also 1857,127 for another example of revenge. 
${ }^{16} \mathrm{ClA}$ Report, 1843.361. See also 1869.191 for an example of another agent who did the same for a later smallpox outbreak. The government had appropriated \$5,000 for the purpose of vaccinating the Indians. Vaccinations were carried out at this time by scraping away the skin and applying the vaccine. This procedure was not easy for agents to carry out

${ }^{17} \mathrm{ClA}$ Report. 1849, 1162

${ }^{19}$ CIA Report, 1853, 355

$19 \mathrm{lt}$ is generally argued that Indians were moved onto reservations after 1850 in any large numbers because of enormous land pressures exerted by white settlers. See Robert H. Jones, "Industrial Society and the Opening of the West," in The American Indian Experience: A Prafile. Philip Weeks, ed. (Arlington Heights, III., 1988), 121-134.

${ }^{20} \mathrm{CIA}$ Report, 1844, 412 and 448; 1852, 370; 1858, 103

${ }^{21}$ CLA Report, 1858, 227. See also 1858, 222.

22 By the end of the century, the salary had been raised to $\$ 1,200$ annually. See Allen. "Agency Physicians to the Southern Plains Indians," 319.

${ }^{23}$ CIA Report, 1846, 268

${ }^{24}$ CIA Report, 1847, 859

${ }^{25}$ CIA Report, 1850, 117. See also 1856, 72 which states that intemperance was the leading cause of death.

${ }^{26} \mathrm{ClA}$ Report, 1875, 301

${ }^{27}$ CIA Report, 1883, 9

${ }^{28}$ CIA Report, 1859, 72. See also 1859, 69

${ }^{29}$ See CIA Report, 1876, 16.

${ }^{30}$ CIA Report, 1857. 397

"Brian Dippie, The Vanishing American: White Attitudes and U.S. Indian Policy (Middletown, Conn., 1982), 97

32 Ibid.

"CIA Report, 1873, 273; 1883, 164; 1860, 426; 1866, 150-51; 1874. 315

:4 Further readings on the Christian Reform movement include Robert Keller, American Protestantism and United States Indian Policy (Lincoln. Neb., 1983); Michael Coleman, Presbyterian Missionary Attitudes Toward American Indians, 1837-1893 (Jackson, Miss., 1985).

"s Robert Mardock. The Reformers and the American Indian (Columbia, Miss., 1971), 2-3.

${ }_{36}$ Prucha, The Great Father, 623

"Ibid., 621-622

${ }^{38}$ For more information on the Dawes Act and the campaign to assimilate the Indians, see Henry Fritz. The Movement for Indian Assimilation, 1860-1890(Philadelphia, 1963); Ronald Berthrong. The Cheyenne and Arapaho Ordeal: Reservation and Agency Life in the Indian Territory, 1875-1907(Norman, Okla., 1976); U.S. Bureau of Lducation. 
Indian Education and Civilization (Washington D.C., 1888); and Prucha, The Great Father, as cited previously.

${ }^{39}$ U.S. Congress, Office of Technology Assessment, Indian Health Care (Washington D.C., 1986), 8

${ }^{40}$ Allen, "Agency Physicians to the Southern Plains Indians," 319

${ }^{41}$ W.F. Bynum, E.J. Browne, and Roys Porter, eds., Dictionary of the History of Science (Princeton, N.J., 1984), 77

42 John Duffy, The Sanitarians: A History of American Public Health (Chicago, 1990), 21

43 Ibid., 20. See CIA Report 1845, 514 for an example of this idea.

${ }^{44}$ George Rosen, A History of Public Health (Baltimore, 1993), 264

4s Ibid., 83-85

${ }^{46}$ Roy Acheson and Elizabeth Fee, eds., $A$ History of Education in Public Health (Oxford and New York, 1991), 32. For further information on the contagion theory and bacteriology please see Charles E. Rosenberg, Explaining Epidemics and Other Studies in the History of Medicine (Cambridge, 1992); William Bulloch. The History of Bacteriology (London, 1938); Hubert Lechevalier and Morris Solotorovsky. Three Centuries of Microbiology (New York, 1965); Owsei Temkin, "An Historical Analysis of the Concept of Infection." The Double Face of Janus and Other Essays in the History of Medicine (Baltimore, 1977); and Erwin H. Ackerknecht, "Anticontagionism Between 1821 and 1867," Bulletin of the History of Medicine 22 (1948), 562-593.

${ }^{47} \mathrm{See}$, for example, CIA Report, 1846, 243; 1853, 382 and 396; 1858, 292.

${ }^{48}$ Refer to CIA Report, 1880, 275 for an example of such a table.

${ }^{49}$ See, for example, CIA Report 1894, 224.

${ }^{30}$ This policy statement only formalized what Commissioners had demanded from physicians for the previous decade.

31 United States Department of Health, Education, and Welfare, Health Services for American Indians (Washington D.C., 1957), 87.

32 See CLA Report, 1880, 42 for one example of an agent making a connection berween improving the health of Indians through the adoption of the customs of whites. Also 1882, 79; 1882, 124.

53 CIA Report, 1864, 312

${ }^{44}$ CLA Report, 1882, 113. See also 1876, 7; 1878, 28; 1894, 218.

"S CIA Report, 1893, 232. See also 1874, 296.

${ }^{36} \mathrm{CIA}$ report, 1874,314

${ }^{57}$ CIA Report, 1894, 223; 1872, 673. See also 1875, 285-6, 1894, 218. ${ }^{s 8}$ CLA Report, 1879, 252. See also 1874, 276; 1875, 298; $1882,17$.

${ }^{59}$ CLA Report, 1875, 291

${ }^{60}$ See CLA Report, 1879, 154; 1880, 58; 1893, 244. It seems that agents also discouraged Indians from living in tepees because they were not permanent. It was more difficult to control Indians and to keep track of them if they were able to pick up their belongings and leave. 
Physicians also made the connection between the nomadic lifestyles of Indians and the subsequent difficulties in rendering medical services. Sec, for example, CIA Report, 1879, 101; 1886, 22.

${ }^{61}$ CLA Report, 1882, 9

${ }^{62}$ CIA Report, 1890, 73. See 1878, 48; 1894, 222.

${ }^{63}$ For examples, see CIA Reports, 1864, 418; and 1854, 290.

of Vogel, American Indian Medicine. 256

${ }^{65}$ CIA Report, 1893, 272

${ }^{66}$ CIA Report, 1893, 277

${ }^{67} \mathrm{See}$ CIA Report, 1854, 290 as one example.

${ }^{68}$ See, for example, CIA Report, 1852, 399.

${ }^{69}$ CIA Report, 1849, 1145

${ }^{70}$ CLA Report, 1894, 164. See also 1886, 222.

$"$ For more discussions on the mission schools and their aims, see Francis Prucha, The Churches and the Indian Schools: 1888-1912 (Lincoln, Neb. and London, 1979).

72 ClA Report, 1883, 147

${ }^{73}$ Beginning in the 1870 's, reports specifically monitored the progress of Indians in the area of civilization. The reports often would contain headings such as "education," "agriculture," "sanitary," and "civilization."

${ }^{14}$ Vogel, American Indian Medicine, 35

75 CIA report, 1883, XLIII. See also his report in 1884, XXXVI.

${ }^{76}$ CIA Report, 1882, 157

77 See the CIA Reports, 1876, 93; 1878, 62; and 1881, 22 for some excellent examples of the argument about civilization. These ideas were also reinforced in examining the adjectives used to described physicians, such as intelligent, rational, and sympathetic, versus those used to describe the medicine men. See 1879, 102; 1880, 33; 1884, 151; $1851,328$.

${ }^{78}$ Many reports mentioned a reliance on the use of incerpreters, though undoubtedly some agents and physicians did comprehend one or more tribal languages. The Meriam Report discusses how, still in 1928, many physicians had to rely on interpreters, especially when dealing with older patients. See page 223.

${ }^{79}$ Harris Coulter has done a study of different schools of thought in medical practice and the conflict between scientific and botanical (Indian influenced) medicine. See Harris Coulter, "Political and Social Aspects of Nineteenth Century Medicine in the United States: The Formation of the American Medical Association and its Struggle With Homeopathic and Eclectic Physicians," PhD dissertation, Columbia University (Ann Arbor, Mich., 1972). See also William Rothstein, American Physicians in the Nineteenth Century (Baltimore, 1972); Joseph Kett, The Formation of the American Medical Profession: The Role of Institutions. 1780-1860 (New Haven. Conn., 1968). 
${ }^{80}$ CIA Report, 1874, 235

${ }^{81}$ CIA Report, 1862, 405

${ }^{92}$ CIA Report, 1875, 337

83. CIA Report, 1875, 337. See also 1883, 74; 1852, 364.

(4) CIA Report, 1862, 430

as See, for example, CLA Report, 1894, 290.

${ }^{86}$ CIA Report, 1875, 296. See also 1893, 120.

${ }^{87}$ CIA Report, 1876, 26

CIA Report, 1878, 115

${ }^{89}$ CIA Report, 1884, 151

${ }^{\circ}$ CIA Report, 1877, 126

' CIA Report, 1853, 382. See 1883, 74 for another example.

${ }^{22}$ CIA Report, 1883, 74

${ }^{93}$ CIA Report, 1881, 14; 1882, 161; 1883, XLIII, 1883, 144; 1886, $\mathrm{XL}$

${ }^{94}$ CIA Report, 1903, 334

"s See, for example, CIA Report, 1859, 405.

${ }^{96}$ Gregory Campbell has argued that "Hospitals, for example, were not constructed to isolate infectious Indian people or to provide a sanitary location to perform medical services, but were constructed to 'civilize' sick Indian people away from tribal influences." The Reports, however, clearly show that physicians were not so single-minded in their motives, and were extremely concerned about the sanitary aspects of this issue. Gregory Campbell, "The Changing Dimension of Native American Health: A Critical Understanding of Contemporary Native American Health Issues" American Indian Culture and Research Journal 13,3\&4 (1989), 2, as quoted from his unpublished manuscript "Medicine as Civilization: American Indian Health Care Under the Bureau of Indian Affairs," (1989).

${ }^{97}$ For examples of cases where the need for hospitals was articulated, see, CIA Report, 1872,$635 ; 1855,388 ; 1859,406 ; 1862,424 ; 1864,100$; $1872,717$.

${ }^{98}$ CIA Report, 1879, 148

${ }^{99}$ ClA Report, 1893, 314

100 CIA Report, 1877, 101. According to a report by Commissioner Hiram Price, Indians often expected to be cured by a single dose of medicine, and if not, "he becomes discouraged and thinks the medicine is of no value and will take no more. Again, he thinks that if a spoonful of medicine will benefit him, a bottle-full must necessarily do him a proportionate amount of good if all taken at one dose." CIA report, 1883, XLIII.

${ }^{101}$ Richard Dunlop, Doctors of the American Frontier (Garden City, New York, 1965), 5. See also Marshall Raffel and Norma Raffel, The U.S. Health System: Origins and Functions (New York, 1989) and W.G. 
Rothstein. American Physicians in the Nineteenth Century (Baltimore and London, 1972).

${ }^{102}$ Allen, "Agency Physicians to the Southern Plains Indians," 319

${ }^{103}$ CIA Report, 1902, 183

${ }^{104}$ CIA Report, $1890,76-77$

ins ClA Report, 1890, 186-7

${ }^{106}$ CIA Report, 1886, 52. See also 1885, 244.

${ }^{10}$ CIA Report, 1886,45

${ }^{108}$ CIA Report. 1874, 314

${ }^{109}$ CIA Report, 1851,$328 ; 1882,157$

${ }^{110}$ CIA Report, 1877, 180

11' CIA Report, 1879, 111. Another agent noted that Indians resorted to "jugglery over the hopeless cases." 1876, 83.

112 ClA Report, 1878, 45. In addition, see 1878, 124; 1893, 161. An Arizona agent noted that because the physician in his agency was incompetent, Indians have "lost confidence in the American medicine man and the Indian medicine men have taken advantage of it." 1890 , 3.

${ }^{113}$ CIA Report, 1876, 102

114 See CIA Report, 1875,228 or 1880,58 for other good examples of physicians gaining the confidence of Indians who subsequencly followed their advice with diligence. Another dimension to this issue could be that Indians who did not like their medicine man may have been drawn toward the physicians for treatment. There is, however, no indication of this in the reports.

11' CIA Report, 1894, 290

116 CIA Report. 1903, 315

"17 CIA Report, 1876, 26. See also 1883, 74.

118 CIA Report, 1880, 30

119 CIA Report, 1877, 136

${ }^{120}$ CIA Report, 1890, XXII

121 For information on Susan LaFlesche see Valerie Sherer Mathes, "Susan LaFlesche Picotte: Nebraska's Indian Physician, 1865-1915." Nebraska History 63.4, 502-530.

122 CIA Report, 1893, 254

${ }^{123}$ The Meriam Report, 222-223

124 The Report contains 150 pages on the woeful inadequacy of the Indian health care system. Complaints consisted of the following: too few physicians covering hopelessly large areas, poor transportation, poor hospital facilities, lack of equipment and medicine, the need for medical specialists, and poor salaries for physicians did not attract physicians with high qualifications. Many Indians still lived in poor sanitary conditions with poor diets as a result of the lack of medical personnel.

${ }^{125}$ For a good example of this concern see CIA Report, 1851, 513. 